\title{
Civil Liability of Employers against Workers
}

\author{
Keyvan Daryabeigi Balvardi ${ }^{1}$ \\ ${ }^{1} \mathrm{MA}$ of International Economic Commercial Law, Tehran University, Kish International Campus, Kish, Iran \\ Correspondence: Keyvan Daryabeigi Balvardi, MA of International Economic Commercial Law, Tehran \\ University, Kish International Campus, Kish, Iran. E-mail: keyvandaryabeigi@yahoo.com
}

Received: May 1, 2017 Accepted: May 23, $2017 \quad$ Online Published: June 1, 2017

doi:10.5539/jpl.v10n3p151 URL: https://doi.org/10.5539/jpl.v10n3p151

\begin{abstract}
The aim of this study was to determine civil liability arising from the exercise of employee and employer. The terms of realization of civil liability include the general and specific conditions and of important theories about civil liability of employers against workers is the risk and fault theory. The popular legal opinion is that employer's liability is based on the fault assumption which refers to a fault-based liability where the fault is assumed and doesn't need proof. But it seems the base of sum of the employer's liability is sum and integration of risk theories and the fault assumption because in the fault assumption we see the individual's assumed liability that he/she can proofing lack of fault or failure come out from liability burden. Despite the respect for civil rights doctrine, in the opinion of the writer (author) perhaps we can't present a recorded and definite basis for employer's liability, as most lawyers believe. So what is in the law is the collective result of the integration fault assumption and derivatives of risk theory. In this study, conducted using descriptive - analytical, to identify the various intellectual foundations on raised issue, the Legal Opinions, law of common law and Romano-Germanic in this article are referred to different approaches on the issue ahead be explained.
\end{abstract}

Keywords: civil liability, employer, worker, risk theory, the theory of fault

\section{Introduction}

In today advanced societies with the increasing development of science, technology and industry alongside consolidation of freedom of market principle and division of labor, countless workshops and factories are operating in manufacturing and services daily. Following the daily activities of the workshops, certainly heterogeneous legal issues arise that are born of the new civilization of human society and economy governance on human societies. Losses incurred as a result of the workplace are one of these issues that can be investigated in the two distinguished fields of internal damages (costs) and external damages (costs). Internal damages are damages as a result of founders of workshop action imposed (entered) to individuals working it the workshop, while, external damages refer to damages entered from workshop area, including employers and employees to third parties unrelated to the workshop.

Certainly any damage causes liability (obligation) for its creator. The liability itself is divided on two types of civil and criminal.

In this study, we have tried to address the second type of damage namely damage caused by acts of employer and employee. From a variety of liabilities, we will study civil liability.

In addition, to knowing the basics of different ideas on the subject in question, we will also glance on the Legal Opinions, Roman Germanic law and common law in order to the ahead different approaches on the issue be explained.

The definition of employer

Two general definition of the concept of the employer can be offered:

1) The common definition: unspecialized concept of employer in the minds of the public is a person who by his/her order and action being done by the forces of another human (Heidarian, 2010, p. 14, Iraqi, 2011, p. 16).

2) Legal definition: a topic that has always been a place of discussion by law professors and courts is the fact that the worker, contractor and employer sometimes act very similar to each other and are confused with each other. 
Certainly, the intended notion (concept) does not include the concept contract in the civil liability law of act twelve on employer's liability for worker's practice the working. Therefore, it is necessary scrutinizing the Statute book of our country give a proper definition of the employer. What is understood from the content of labor law (Article 3 and Clause 1 of Article 13 of the Labor Law) and paragraph 4 of Article 2 of the Law on Social Security is defined as follows:

The employer is a natural or legal individual (entity), which the worker according to his/her apply and account works in return for wages and managers and directors of the workshop are representatives of the employer and the employer is liable for all obligations which representatives said the workers (Ahmadvand, without date, $\mathrm{p}$. 29).

There is also a subtle difference between definition of worker and contractor, yet lack of exact understanding of this difference will lead to an improper track in the understanding of employment relations and eventually holding liable a person in accordance with Article XII of the law of civil liability, and this is contrary to justice and legal principles.

\section{Three Criteria to Distinguish Employees and Employers}

Three distinction criteria have been offered between employee and contractor

1) The economic compliance with the

2) Administrative compliance

3) Employment relations in accordance with labor law

Supporters of economic compliance theory point out that the worker is who is economically dependent on the employer and his/her living (feeding) based on the income resulted by employer's payment. It is undoubtedly incomplete and inaccurate, because includes even the employees and contractors and has been provided very broad, while civil liability law approach in the naming of worker is a more specific and narrowed definition. Thus, the proponents of administrative compliance with the presentation of this approach state that the criterion for the identification of workers is his/her obedience from employer in the entire process and during the employment relationship and the purpose of compliance is legal compliance, not economic (Ghasemzadeh, 2000, p. 263). With this definition, contractor is excluded from the circle of inclusion. However, with regard to the provisions of social security and labor law, it can be seen that in the definition of worker, we should take one more step and consider the criterion as the employment relationship that according to the rules mentioned above, the requirement of proof and continuing the employer relationship is working. This means more accurate in the definition of worker, is the sum of administrative compliance (the obedience system) and employment criterion as administrative tribunals such as the discernment council, conflict resolution and so on, actually require both mentioned cases to be considered as employer-worker relationship.

\section{The Philosophy of Civil Liability of the Employer}

According to the vast majority of law professors, employer's liability against workers' practices who working under her/his supervision is liability arising from other's action as well as consider it causality, and believe that the employer is a stronger cause than foreman (worker) and therefore he/she is the main liable. Although this idea has been criticized: (because workers covered by labor law is a sane and authorized person, the custom knows considers him/her stronger than the employer and aside from that, if the employer's liability is due to stronger view of foreman, this is no longer the liability arising from other's action and there should be no possibility of recourse to the worker while act twelve of civil liability law has predicted referring to the worker (Bahrami Ahmadi, 2009, p. 191). In addition, whether in jurisprudence or in progressive jurisdictions, the liability arising from another act is anomaly and the principle is personal responsibility (liability). As a result, the liability arising from other's action is an exceptional item and needs case stipulation in the letter of the law.

\section{Terms of Realization of Civil Liability of the Employer}

\section{1) General Conditions}

General conditions for the realization of employer's civil liability include: losses entry, harmful act and causal relationship (Katoozian, 2000, p. 241)

2) The specific conditions

According to Article XII of the law of civil liability (Employers who are subject to labor law are liable to compensate the damages that are entered by staff or workers during work or on the occasion of it unless it is established all the precautions that situation and circumstances required have been taken, or that even if 
precautions shall have been taken, the prevention of the suffered damage is not possible, the employer can refer to damage agent if according to law be held accountable. we find that specific conditions employer liability can be cited:

The employer is subject to labor law.

The damage is entered during work oron the occasion of it (Ahmadvand, No. 61, p. 29).

As a result, it is clear that if the employment relationship is not in accordance with the working provisions of the Labor Law, or damage isn't entered as a result of work or on the occasion of it, the worker himself is personally liable for damages.

\section{The Most Important Theories about Civil Liability of Employers against Workers}

About reason for accepting employer's civil liability for the actions of the employer's workers some ideas have been presented which below are a few of them:

The theories subset of the theory of risk

1) The absolute risk

According to this idea (theory), the employer's liability and all the economic, production and service rulers for their wage earners' actions is absolute and nothing can absolve him/her of his/her liability (responsibility). In this case, there is no need to prove fault because basically the basis of this idea (theory) is non-fault liability and only with proof of employment relationship, loss, damage and direct relationship of incurred damage (loss) to the employer's current employees can be fulfilled. The idea (theory) that derived from the traditional teachings of common law legal system today isn't very popular because the opponents of this idea (theory) believe it isn't close to justice the liability arising from other's act be in any case absolute and inviolable. In addition, if we accept the absolute risk theory, as a result we must also say that the possibility revisit the employer to the worker not exist while in accordance with the law, the employer is permitted in the case of proof of the fact that all the principles and rules of technical are respected and if they would respected, the damage yet is entered, refer to workers liable for damages to compensate.

2) The risk versus benefit

According to this theory (idea), which in addition to international lawyers such as Josserand (Josserand, without date, vol. 2, p. 68) and Bertrand, has also in Imami jurisprudence many proponents, and perhaps it can be taken into account in popular opinion in jurisprudence, the employer is the main benefited of activity conducted in workshop and the main benefit goes to his account and thus should be the main burden of responsibility on his/her shoulders. This means that the employer for the interest awarded to him caused by the workers' action, has also implicitly admitted the responsibility risk for the later potential damage. As professor Katoozian in support of this theory believes that social justice requires the person who benefits from the activity must also accept responsibility (liability) for it. According to this theory, we wouldn't be encountered with the objections theory of absolute risk, because the next worker's referral to employer which has been stipulated in Article twelve of civil liability is possible. However, this theory has also been faced with the opponents' challenge. According to the opposition, accepting the responsibility for profit is fair, but the basis of employer's liability is on the fault. This means if we accept the theory of risk versus benefit, we implicitly have removed the responsibility from fault, but the basis of employer's liability is on the fault.

\section{The Theories (Ideas) Subset of the Theory of Fault}

1) The fault caused by mismanagement and taking care of workers

According to this opinion (idea) expressed by Bertrand and English jurist named Black Stone also believes it, the employer's liability (responsibility) to the worker's actions is on the basis of the employer's fault and this fault caused by poor management and oversight by employers to his/her workers which has led to such damage. Bertrand says: (employer for all civil offenses which made by his/her workers and he/she does not prevent, is responsible). This theory matches with the spirit of the law of civil liability and the end of its act twelve which states that: (If necessary precautions are brought into action, the prevention from loss was not possible...). Because in both these cases, the employer's liability is considered based on misconduct (mismanagement) and the act of above law allows the referral in the case of proof the proper management to worker.

2) The fault caused by adverse selection of work

This theory (idea) which has little supporters offered by Francis and Pottier and Pottier in its defense says: the employer because of adverse selection is responsible (liable) for the fault and pseudo-fault of workers. 
These two theories in Iran and France met with serious objections that the most important of it is that the employer could legally be a minor, therefore, the adverse selection or mismanagement on the part of the minor is meaningless and the a minor can't be considered as compensation guarantee (liable) for lack of proper choice of worker or lack of suitable oversight on him/her.

\section{3) Representative (agent)}

According to this theory, the employer with hiring workers, voluntarily trust him in proper conducting of the workshop and so at the end, when the time comes damages, on behalf of the workers, compensates the losses (damages). In fact, this theory holds that the employer is representative of worker against the victim (affected). This opinion (idea) hasn't also been spared from criticism of the opposition. The opponents state critically first, the accepting of this opinion (idea) is based on accepting workers and employers alliance, while this assumption will never happen. Second, in the case of accepting representative, at all the time the next worker's referral to employer to compensated losses should be possible, but it can't be seen in the rules (Ahmadvand, No. 61, p. 17).

\section{4) Guarantee the right}

According to this theory, the basis of employer's liability (responsibility) is his/her guarantee to worker that is why it is known in English law as guarantee theory. According to this theory the employer with employment of worker accept non-written contracts and that later can be a source of effects. One of his/her guarantees of the workers is for damages during and on the occasion of it comes to third person. Based on this idea (theory) the originality of worker toward his/her works is preserved, with this difference that the liable compensates the losses (damages).

This theory has also been criticized and it is that if the basis of employer's liability is guarantee, thus in accordance with the spirit and rules of the contract of liability, the affected person in selecting individual to refer is free between liable and the worker, while according to letter, the effected person should refer only to the employer (previous, $\mathrm{p}$ 17).

\section{The Compensation Liability of Damage Arising from Workers' Actions}

In terms of responsibility (liability), the principle holds the compensation by employer for damage caused by worker's acts and actions. However, according to the text (letter) of Article XII of the Civil Liability Act this principle is not inviolable, in other words, the burden of responsibility (liability) can be removed from the employer's shoulders under certain circumstances and consider the prejudicial worker as liable.

It should not be forgotten that this does not disclaim the employer's liability, but according to the law, the employer must continue to do compensation with this difference if meet certain conditions for those compensations for the losses can refer to worker.

These include:

1) The damage has already been compensated by the employer.

2) Compensation is also depending on the cases could be one of two modes of "restore the former state" or "giving the equivalent" (previous, P 35).

3) The worker's fault to be proven.

4) The proof of required precautions on the part of the employer or its uselessness (previous, P 29).

The proof burden of all of the above-mentioned cases is on the employer, that's mean in the case failure to prove the triple, the employer is absolute liable, but if they are proven, he/she is entitled to refer to worker.

\section{The Study of Guilt (Fault) Assumption and the Presumption of Guilt}

The guilt (fault) assumption and the presumption of guilt are among principles of guilt (fault-based) responsibility (liability). This means that in both these fundamentals, the basis of being warrantor (liable) is the fault of committed. But expressing the difference of these two fundamentals, it is necessary to be explained separately.

\section{The Guilt (Fault) Assumption}

The guilt (fault) assumption means that we assumed the warrantor's fault in damages and without having to prove that, for compensation we refer to liable (responsible) unconditionally. Sometimes this basis is confused with risk theory, but it must be recognized that they are seriously different with each other.

In the risk assumption, the liability (responsibility) isn't fault-based and merely establishing the causation between the committed acts and the damage, he/she will be responsible (liable) for damages. But in the fault 
assumption, the basis is fault-based, but this fault is considered fixed in fate (nature). The difference is in the fault assumption, the liable (responsible) person can proves some cautions and precautions and gotten rid of responsibility (liability) burden. For example the Article XII of the Civil Liability Act, which provides: (... unless it is established that all precautions the circumstances of the case required have been taken or that if such precautions are taken to act, the prevention from the suffered damage was not possible, the employer can refer to prejudicial person if in accordance with the law held liable (responsible). This implies that in the fault assumption, with proving that fault which previously assumed, can be removed from the responsibility (liability). But in the responsibility (liability) based on risk, the liability essentially isn't fault-based that the proof no-fault be helpful.

But the responsibility not fault the proof of fault-based liability risk essentially be useless.

\section{The Presumption of Guilt}

The presumption of guilt is another type of fault-based liability which in contrary to the fault assumption described above, the warrantor's fault isn't assumed. But the legislator states condition or conditions in the law that if they realized the perpetrator's fault is proven. Its major difference is also the burden of proof. In the liability based on fault presumption, the principle is that the perpetrator is not liable (responsible) unless circumstances stated by legislator are realized that its proof is also the responsibility of guilt (fault) pretender. But in the fault assumption, the pretender (claimant) of lack of fault must prove the integrity and non- fault (Katoozian, 2001, p. 183).

\section{The Comparison of the Effects of Presumption and Assumption of Guilt}

The effects of assumption and presumption of fault can be seen in three separately divisions:

1) The effects of presumption and assumption of fault to worker

The assumption of guilt: accepting the basis of presumption of guilt (fault) lead to this that the worker isn't warrantor and only if that is not the fault of the employer and proves his/her non-fault can refer to worker.

The presumption of fault (guilt): accepting the presumption of fault (guilt) lead to this that because the worker is fault (guilt) doer, be directly liable (responsible) unless can prove legal presumptions indicating employer's fault.

2) The effects of presumption and assumption of fault to employer

The assumption of guilt: in the case of accepting the assumption of fault, the employer must be at all-time responsible (liable) for compensation unless prove the exemptions contained in Article XII of the Civil Liability Act (no fault).

The presumption of guilt: in this case, the employer essentially isn't responsible (liable), unless the worker as prejudicial or the affected person can prove his/her guilt.

3) The effects of presumption and assumption of fault to effected (victim)

The assumption of guilt: the effected (victim) in the case of accepting the assumption of guilt should refer to someone who is considered legally guilty, who in the subject of our discussion is employer.

The presumption of guilt: in this case, the effected (victim) should go to the person who according to legal presumptions has had fault and is warrantor.

\section{The Investigation of Employer's Liability from the Perspective of Islamic Law, Common Law and Roman-Germanic Law}

1) The employer's liability from the perspective of Islamic law (jurisprudence)

Undoubtedly, the Imami jurisprudence is considered as a based resource, thus, it is appropriate to ask its opinion.

In jurisprudence there is no history for the exact definition of employer and worker and most of the materials are around overviews are visible in expressing boundaries of details in it.

In the Shiite (Imami) jurisprudence there is texts and rules that the judgment of the subject of what we are in can be extracted from it.

According to the owner of the Javaher, enjoying another job required to take his/her liability (responsibility) which in this sense, we can be guided to the absolute risk (Najafi, without date, vol 37, p. 38). Ayatollah Mohaghegh Damad in the rules of Islamic jurisprudence, has pointed out that someone benefiting from other's 
work is his/her warrantor (liable) (Mohaghegh Damad, 2004, p. 74) ${ }^{1}$.

There are also rules as if these judgments derived from them. This base (risk versus benefit) is consistent with the rule of "anyone who has the interest, he/she will be responsible (liable) for damages" (Ahmadvand, without date, p 14). The concept of mentioned rule is that the benefited from action which enjoy it, should accept the damages arising from it. In addition, the tax liability rule can also confirm the theory of risk versus benefit which has been discussed in the worthwhile Shiite (Imami) jurisprudence.

In conclusion, the approach that can be understood from juridical laws and regulations is the acceptance of the theory of risk versus benefit is a matter of particular interest to jurists and its documentations have also been correctly referred and considered.

2) Employer's liability (responsibility) from the perspective of common law

In the English law civil liability of the employer has long roots. Many views (theories) have been stated and most of them roots in the Industrial Revolution and the problems related to it. What is now considered and in the common law doctrine has attracted the attention is the subject of "Creating a safe environment"(Praser and Keaton, without date, p. 43). This safety (security) has two aspects:

\section{Worker's Security}

\section{Third party's security from labor's action (operation)}

This means the employer must provide a safe environment for worker in order to in the shadow of this safety both workers and third parties to be safe from workshop activities.

In other words, mere occurrence of accident and damage is a presumption of the failure of the employer to provide a safe environment and in fact this behavior is "violation of behavior that law requires as minimal support from others (worker) against unconventional threat that" ${ }^{2}$.

What in addition to it has been regarded is oversee to careless worker that is also the responsibility of the employer and it has been said that he/she even in case of unforeseen events, without premeditation or worker's carelessness is liable (responsible) ${ }^{3}$.

Under common law legal system, the liability principally is fault-based however, to justify the absolute responsibilities such as employer's liability it has been said: Everyone who provide dangerous environment, has committed fault (Ahmadvand, without date, p. 14).

From what has been said, seemingly employer's liability in English law is based on the theory of risk.

However, for other fundamentals many arguments have been also presented, for example, the theory of vicarious liability (representative) also has a lot of proponents. But basically, philosophy of accepting the risk and its derivatives is based on the following rules (criteria):

Control rule: this means because the employer is aware of all movements and activities of workers and, moreover, also has the right to control and monitor, as a result, is deemed responsible (liable) for their actions.

Other popular rule (criterion) is "richer employer", that is because the employer is richer than workers, according to the requirement of justice, he/she is responsible for compensation.

Economic benefit rule (criterion): This indicates because the employer benefits from major activities of workers, thus the major responsibility with him (previous, P 14).

3) The employer's liability from the perspective of Romano-Germanic law

Employer's liability is different in Iranian and French law. In the French legal system the employer's liability is absolute. This basis for absolute civil liability of the employer has been predicted in the article 1384 of France law.

According to Article 1384 of the French Civil Code which addresses civil liability of diverse groups such as teachers, employers, and so on: (employer and masters are responsible (liable) for the losses occurred from the employees and workers who they have hired $)^{4}$. In other words, in this mode, the employer under all

\footnotetext{
${ }^{1}$ Whenever a person take forced labor a free person and force him to use, or not to force and violence but asking him to do work, he/she would be his warrantor (liable).

${ }^{2}$ Katoozian - Amir-Naser - Requirements out of contract - the general rules of fault - previous - Page 355

${ }^{3}$ the employer can be liable despite the fact that the harm was unintentional and neither he nor any of his employees were careless

${ }^{4}$ Civil code, Art 1384 , : Les maîtres et les commettants, du dommage causé par les domestiques et préposés dans les fonctions auxquelles ils les ontemployés
} 
circumstances is always liable to compensate the damages caused by the act of worker and this itself indicating the difference between civil law approach of France and Iran.

As it has previously been stated that the approach of Article XII of the civil liability law of Iran is that if employer prove his/her non-fault can refer to the prejudicial worker, in the French legal system such a possibility does not exist and the employer has the total responsibility (liability) and thus merely taking causal relationship is sufficient (Angell, without date, p. 18).

However, some experts believe that the guarantee of the French Civil Code as the responsibility (liability) base set forth in Article XII of the civil liability law is a certain guarantee and does not match with none of the principles of liability (Ghasemzadeh, 2000, p. 263; Hosseinnejad, 2010, p. 52).

\section{Conclusion}

Legal popular opinion is that the employer's liability is based on the fault assumption. As mentioned, fault assumption refers to fault-based liability (responsibility) which the fault is assumed in it and doesn't need proof. What is seen about employer in the article twelve of civil liability law, largely expresses the same basis.

But maybe we can't exactly consider the fault assumption as the basis of employer's liability. Even perhaps no single and clear basis can be said for it. But it seems the basis of employer's liability is the sum of and integration of risk, theories, guarantee the right and fault assumption. This is because in the fault assumption we see the individual's assumed liability that he/she can proofing lack of fault or failure come out from liability burden. But what we can see in the Article XII of the civil liability law is that the employer in case of proving non-fault, continue to be responsible for the compensation to the first damage against effected with the difference that the law obscurely only grants the right to referring (recourse) worker to him. And the fact that in any case the employer is the target of affected person (even in the case of proof non-fault) we are led to the theory of risk and its derivatives. Although we can't also absolutely accept the risk theory because in the case of accepting the risk theory, liability would be non-fault-based and proving non-fault would be ineffective (useless), while according to the provision mentioned above, proving non-fault of employer will be the origin of effects. As a result, . Despite the respect for civil rights doctrine, in the opinion of the writer (author) perhaps we can't present a recorded and definite basis for employer's liability, as most lawyers believe. So what is in the law is the collective result of the integration fault assumption and derivatives of risk theory.

\section{References}

Ahmadvand, V. (n.d.). The comparative study of civil liability of employers in the legal system of Iran an England. Faculty of Humanities, 61.

Bahrami Ahmadi, H. (2009). civil liability (1st ed.). Tehran, Mizan Publication.

Heydariyan, M. (2010). principles of law. Publications of the Supreme School of Literature and Foreign Languages.

Katoozian, N. (2000). Obligations out of the contract: The compulsory liabilty (2nd ed.). Tehran University Press.

Katoozian, N. (2001). The compulsory liability, obligations out of the contract (Vol. 6). Tehran, Yalda Publication.

Mohaghegh Damad, M. (2004). the juridical rules of civil law section. The Center of Islamic Sciences publishing.

Najafi, M. H. B.-B. (n.d.). Jewelry of word in Islam religions ([in Arabic] Javeher al-kalam-fi-sharye-al-eslam) the Islamic Fiqh Encyclopedia.

Pier Angeli, The Treatise of obligations, No. 13.

Safai, \& Rahimi. (2012). Samt Publication, Fourth Edition.

Zadeh, G., \& Morteza, S. (2000). the principles of civil liability (1st ed.). Dadgostar (Justice) publication.

\section{Copyrights}

Copyright for this article is retained by the author(s), with first publication rights granted to the journal.

This is an open-access article distributed under the terms and conditions of the Creative Commons Attribution license (http://creativecommons.org/licenses/by/4.0/). 